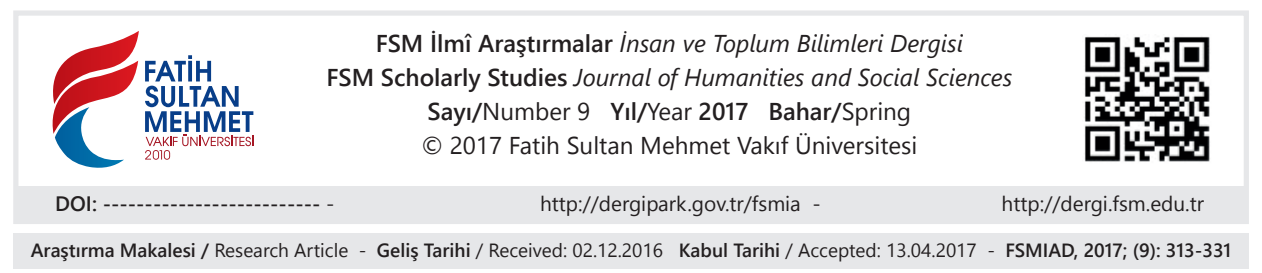

\title{
Hattat Afif İbrahim Efendi
}

Talip Mert*

\section{Öz}

Hattat Afif İbrahim Efendi Osmanlı Hat tarihine adını yazdırmış hattatlardandır. O her ne kadar büyük hattatlar arasında olmasa bile, günümüze ulaşan çok az sayıdaki eserinden onun değerli bir kalem sahibi olduğu açıkça görülmektedir. Afif Efendi hat derslerini Hüseyin Hablî' den almıştır. Kendisi esasen bir devlet memurudur. Öyle olunca da her halde hat onun için bir meslek olmamıştır. Ama çok büyük bir hat merakı olduğu bize intikal eden miras listesinde apaçık görülmektedir. Onun koleksiyonunda görülen yazıların acaba ne kadarı günümüze ulaşabildi? Çünkü bugüne kadar arşivlerde görülen en zengin hat koleksiyonunu Afif İbrahim Efendi yapmıştır. Hafız Osman ve Şeyh Hamdullah gibi hat tarihinin önde gelen üstadlarının yazılarını onun büyük bir şevkle topladığı görülüyor. 85 adet muhtelif türde Hafız Osman, 68 adet de yine muhtelif türde Şeyh Hamdullah hattı toplamas1 onu bu alanda "tek" yapmaya yetecek bir miktardır.

Afif Efendi devrine göre iyi bir de kitap koleksiyonu yapmıştır. Bu haliyle onu değerli bir kültür ve sanat adamı olarak zikretmek gerektiği ortadadır.

Anahtar Kelimeler: Afif İbrahim, hattat, murakka', kıt'a, meşk, sülüs, nesih, hilye.

\section{Calligraphist Afif İbrahim Efendi}

\section{Abstract}

Calligraphist Afif İbrahim Efendi is one of the calligraphers that put his stamp on the Ottoman Calligraphy history. Even if he didn't have a special place among popular caligraphists he had limited number of works that reach the present day and this indicates that he wrote well. Afif Efendi took his calligraphy lessons from Hüseyin Habl. He was ordinarily a public servant. In this case probably calligraphy was not his real job. But his interest in calligraphy can be seen obviously from his list of heritage (muhallefat). How many of the writings in his collection has reached the present day? Because Afif İbrahim Efendi had the richest calligraphy collection that has been in the archives till today. It is obvious that he keenly collected the calligraphies of Hafız Osman and Şeyh Hamdullah who were leading experts in the calligraphy history. He also had a good book collection according to his period. Therefore apparently he was a precious culture and art expert.

Keywords: Afif İbrahim, calligraphist, murakka', kıt'a, meşk, sülüs, nesih, hilye

* Öğr. Gör., Marmara Üniversitesi Fen-Edebiyat Fakültesi Bilgi ve Belge Yönetimi Bölümü, İstanbul/Türkiye, tmert@marmara.edu.tr 
XVIII. Asır hattatlarından Afif İbrahim Efendi hakkında Müstakim-zâde Süleyman Sadeddin Efendi meşhur eseri “Tuhfe-i Hattatîn'de kısaca şu bilgiyi veriyor:

"Şehrîdir. Defterhane kâtiblerindendir. Hüsn-i hatt-l sülüs ve neshi Hüseyin Hablî'den temeş̧̧̧ ile tahsîl-i izn-i ketebe eylemiştir. Vaktimizde şürekâsının munsiflarındandır. (Kâtib-i hüsni'l-hat 1181) tarihi Şaban-ı Şerifi evâilinde rihlet eyledi. Nesih tarafinda mümâreseti kıllet üzere olmağla Mushaf kitâbet eylememiştir." ${ }^{1}$

Hattat Afif İbrahim Efendi'nin hayatı pek geniş olarak bilinmese de onun hayatı boyunca Şeyh Hamdullah ve Hâfız Osman gibi bu işin pîrleri başta olmak üzere birçok büyük hattatın yazılarını cem' etmesi sebebiyle hat tarihinde çok müstesna bir yeri olduğu ortaya çıkıyor. Bugüne kadar muhallefâtı görülen, az da olsa bir kısmı yayımlanan hiçbir hattatın terekesinde bu kadar bol ve kaliteli, üstün evsafı hâiz bir hat koleksiyon yoktur. $\mathrm{O}$ devre göre mütevazı bir hat müzesi de say1labilir.

2005 y1lında yayımlanan bir yüksek lisans tezinde yer alan bilgilere göre Türkiye'de yeri ve sahibi bilinen çeşitli türden 321 adet Hafiz Osman hattı bulunmaktadır. ${ }^{2}$ Ve bu rakam eksiktir. Çünkü şahsen bildiğim çok zengin bir koleksiyon bu eserde yer almamıştır. Ama koleksiyonunda 85 adet Hafiz Osman hattı olan Afif Efendi'nin bu merakı hat ve hattatlar için çok saygı değer, çok hürmete şâyan bir durumdur.

Şeyh Hamdullah'1n mevcut eser sayısı ise $227^{\prime}$ dir. ${ }^{3}$ Afif Efendi bu konuda da oldukça parlak bir koleksiyon yaparak o devirde Şeyh'in 68 eserini toplayabilmiştir. Diğer hattatları da küçümsememek gerektir. O zamanlar muhakkak ki bu yazılar günümüzden çok daha boldu, ama edinmek her halde o kadar da kolay değildi.

Afif İbrahim Efendi’nin bize intikal eden yazısı da oldukça azdır. Görülebilen birkaç yazısından onun tahminlerin de ötesinde değerli bir kalem olduğunu ortaya koyuyor. Daha çok da damadı Osman Efendi'nin imzalarıyla yaşayan, Osman Efendi'nin kayın pederi olarak meşhur olan bir hattattır ve öyle bilinir. Ama Afif Efendi'nin zamanına göre çok derin zevk ve merak sahibi olduğu gerçeği ise bu belgeyle ortaya çıkıyor.

Afif İbrahim Efendi'nin yazıya olan merakı kadar kitab meraklısı olduğu da apaçık ortadadır. Yine takdirle kaydetmek gerekirse o, diğer hattat terekelerinde

1 Müstakim-zâde, Tuhfe-i Hattatîn, İbnülemin Mahmud Kemal neşri, Türk Tarih Encümeni Külliyat1, Devlet Matbaası, İstanbul 1928, s. 50.

2 Ömer Faruk Dere, Hattat Hafiz Osman Efendi, Korpus Kültür Sanat Yayıncılık, Promat Basın Yayın Sanayi Tic. AŞ., İstanbul 2005.

3 Muhittin Serin, Hattat Şeyh Hamdullah, ikinci baskı, Kubbealtı neşriyat nu: 128, Mas Matbaac1lık, İstanbul 2007. 
görülmeyen miktarda epeyce kitaba da sahiptir. Bu kitapların fiyatları göz önüne alınınca hat sanatı yönünden de kayda değer oldukları görülüyor. İbrahim Efendi'nin mahkemece kayda geçirilen ve kültürel açıdan oldukça zengin, özellikle de hat tarihi açısından çok zengin muhallefâtı şöyledir:

"Mahmiye-i İstanbul'da Hocapaşa Mahallesinde sâkin iken bundan akdem vefat eden Mukābele-i Süvari kâtiblerinden merhum Hattat Afif İbrahim Efendi ibn-i Mustafa Efendi'nin verâseti zevce-i menkûha-i metrûkesi Ayşe Hanım ibnetü Mustafa Bey ile sulbiye kebîre kızları Fatma Hanım ve Emetullah Hanım ve sulbiye sağîre kizı Rukiyye Hanım'a münhasıra olduğu şer 'an zâhir ve mütekarrer olduktan sonra sağîre-i mezbûre Ruklyye Hanım'in vâlidesi ve tesviye-i umûruna kıbel-i şer'den vasiyy-i mansûbesi mezbûre Ayşe Hanım ile mezbûretân Fatma Hanım ve Emetullah Hanım taraflarından vekîl-i sâbitü'l-vekâleleri mezbûre Fatma Hanım 'in zevci Hâfiz Ali Efendi ibn-i Hammâmî Mehmed Ăga[nın] taleb ve ma 'rifetleriyle tahrîr ve bey "ve beyne'l-verese taksîm olunan tereke-i merhûm-i mezbûrdur ki, ber-vech-i âtî zikr olunur. Fî gurre-i Muharrem 1182 (18.05.1768).

\begin{tabular}{|c|l|c|c|}
\hline & Kitabın adı & $\begin{array}{c}\text { Adedi / } \\
\text { Cild }\end{array}$ & Fiyatı / Akçe \\
\hline 001 & Tefsîr-i Beyzâvî & & 05605.00 \\
\hline 002 & Van Kulu [Lugatı] & 02 & 05000.00 \\
\hline 003 & Mecmûa-i Eş'âr & & 01005.00 \\
\hline 004 & Şerh-i Kudûrî, beyâbi‘ & & 01100.00 \\
\hline 005 & Cerîdetü'l-Acâib tercümesi & & 00400.00 \\
\hline 006 & İbrahim Halebî & & 04050.00 \\
\hline 007 & Dîvan-1 Nâdirî & & 00300.00 \\
\hline 008 & Şemâil-i Şerif & & 0325.00 \\
\hline 009 & Molla Câmî & 05 & 00605.00 \\
\hline 010 & Hayriyye, alay1 & & 00120.00 \\
\hline 011 & En 'âm-1 Şerif & 05 & 18000.00 \\
\hline 012 & Tefsîr-i Ebü’l-Leys tercümesi & & 00260.00 \\
\hline 013 & Sihâh-1 Acemî, alay1 & & 00660.00 \\
\hline 014 & Sarf Cümlesi & & 021509.00 \\
\hline 015 & Eflâk-1 Melâî? & & 00429.00 \\
\hline 016 & Mülteka'l-Ebhur & & 01105.00 \\
\hline 017 & Fikh-1 Ekber Mecmûası & & \\
\hline 018 & Kudûrî & & \\
\hline
\end{tabular}




\begin{tabular}{|c|c|c|c|}
\hline 019 & Siyer-i Veysî & & 00906.00 \\
\hline 020 & Dîvan-1 Hâfiz & & 00620.00 \\
\hline 021 & Divan-1 Fasîh & & 00400.00 \\
\hline 022 & Tercüme-i Kasîde-i Bürde & & 00312.00 \\
\hline 023 & Külliyât-1 Örfî & & 00660.00 \\
\hline 024 & Hümayunnâme & & 01320.00 \\
\hline 025 & Def'a Siyer-i Veysî & & 00500.00 \\
\hline 026 & Tuhfe-i Şâhan & & 00339.00 \\
\hline 027 & Muhtâr-1 Sihah & & 01554.00 \\
\hline 028 & Zübdetü'l-Kelâm & & 00903.00 \\
\hline 029 & Sadru'ş-Şerî‘a & & 00920.00 \\
\hline 030 & Dîvan-1 Şevket & & 01010.00 \\
\hline 031 & (...) alay1 & 05 & 00320.00 \\
\hline 032 & Şifâ-i Şerîf & & 01705.00 \\
\hline 033 & Dîbâce şerhi, alayı & 10 & 00710.00 \\
\hline 034 & Mushaf-1 Şerîf & 01 & 01900.00 \\
\hline 035 & Fetâvâ-yı Yahya Efendi & & 01290.00 \\
\hline 036 & Şâfiye Şerhi, Seyyid Abdullah & & 00700.00 \\
\hline 037 & Def'a Tercüme-i Kasîde-i Bürde & & 00480.00 \\
\hline 038 & Meşârik-1 İbn-i Melek & & 03370.00 \\
\hline 039 & Şâfiye, alayı & & 00690.00 \\
\hline 040 & Silsilenâme & & 00612.00 \\
\hline 041 & İbâdât-1 Medîne & & 00460.00 \\
\hline 042 & Gencîne-i Saadet & & 00440.00 \\
\hline 043 & Tezkire-i Hasan Çelebi & & 01460.00 \\
\hline 044 & Divan-1 Örfî̀ & & 00510.00 \\
\hline 045 & Divan-1 Kelîm & & 01040.00 \\
\hline 046 & Metn-i Meşârik & & 00420.00 \\
\hline 047 & Ravzatü'ş-Şühedâ & & 00320.00 \\
\hline 048 & Evrâk-1 Perîşan & & 00612.00 \\
\hline 049 & Câmiu's-Sağîr & & 00905.00 \\
\hline 050 & Def'a İbrahim Halebî & & 01820.00 \\
\hline 051 & Lugat-1 Hurufât & & 00096.00 \\
\hline 052 & Def'a Şemâil-i Şerîf & & 00310.00 \\
\hline
\end{tabular}




\begin{tabular}{|c|c|c|c|}
\hline 053 & Şerh-i Tarîkat, Rümûz-i Künûz & & 08000.00 \\
\hline 054 & Def'a Mülteka'l-Ebhur & & 01910.00 \\
\hline 055 & Def'a Molla Câmî & & 00740.00 \\
\hline 056 & Birgivî Şerhi & & 01203.00 \\
\hline 057 & Def'a Metn-i Meşârik & & 01100.00 \\
\hline 058 & Tefsîr-i Celâleyn & & 04806.00 \\
\hline 059 & Kâfiye & & 00081.00 \\
\hline 060 & Mîzân-1 Şa'rânî & & 00501.00 \\
\hline 061 & Def'a Kâfiye ve İzhar & & 00400.00 \\
\hline 062 & Takvim Tarihi & & 00490.00 \\
\hline 063 & Def'a Divan-1 Örfî & & 00500.00 \\
\hline 064 & Tarih-i Taberî ve Tuhfe (?) kıt'ası & & 00600.00 \\
\hline 065 & Şerh-i Hadîs-i Erbaîn & & 00660.00 \\
\hline 066 & Şerh-i Akaaid, alayı & 04 & 00520.00 \\
\hline 067 & Buharî k1t'ası & & 00501.00 \\
\hline 068 & Tarih-i Sultan Mehemmed & 03 & 00560.00 \\
\hline 069 & Hayriye, alay1 & 05 & 00310.00 \\
\hline 070 & Münebbih & 05 & 00670.00 \\
\hline 071 & Tefsîr-i Gurâb & & 04610.00 \\
\hline 072 & Altıparmak & & 03010.00 \\
\hline 073 & Şemâil-i Şerif, li-Aliyyi'l-Kaarî & & 01510.00 \\
\hline 074 & Tarîkat & & 13300.00 \\
\hline 075 & Süleymanname-i Aziz Efendi & & 01860.00 \\
\hline 076 & Def'a Divan-1 Örfî̀ & & 00246.00 \\
\hline 077 & Ahlâk-1 Nâsırî & & 00300.00 \\
\hline 078 & Mecmûa-i Kadri Efendi & & 00840.00 \\
\hline 079 & Mecmûa-i Telhîs & & 00399.00 \\
\hline 080 & Hadîkatü’s-Süedâ & & 00280.00 \\
\hline 081 & Divan-1 Mütenebbî & & 00200.00 \\
\hline 082 & Tarih-i Nişancı & & 00330.00 \\
\hline 083 & Risâle-i Şeyh Murad Efendi & & 00120.00 \\
\hline 084 & Mehd-i Müşterî, alay1 & 03 & 00120.00 \\
\hline 085 & Mesnevî kıt'as1 & & 00150.00 \\
\hline 086 & Def'a Hümayunname & & 01000.00 \\
\hline
\end{tabular}




\begin{tabular}{|c|l|c|c|}
\hline 087 & Hediyyetü'l-İhvan & & 00500.00 \\
\hline 088 & Divan-1 Kâtibî & & 00080.00 \\
\hline 089 & Cinânü'l-Cinân & & 00550.00 \\
\hline 090 & Âdâb Cümlesi & & 00330.00 \\
\hline 091 & Fezâilü'l-A'mâl & & 00400.00 \\
\hline 092 & Mantık Cümlesi & & 00180.00 \\
\hline 093 & Hâşiye (...) & 05 & 00250.00 \\
\hline 094 & Risale-i Kudsiyye, alayı & 05 & 02000.00 \\
\hline 095 & Miftâhu'l-Felâh, alay1 & & 00069.00 \\
\hline 096 & Hâfız Şemsi ve Gülistan kit'ası & & 00360.00 \\
\hline 097 & Lügat-1 Sübha, alay1 & & 00120.00 \\
\hline 098 & Şerh-i Çağminî & & 00711.00 \\
\hline 099 & Tercüme-i Bend & & 00321.00 \\
\hline 100 & Hilye-i Hâkānî maa Veysî & 10 & 00400.00 \\
\hline 101 & Hidâyetü'l-Hidâye, alayı & 03 & 00150.00 \\
\hline 102 & Risâle, alay1 & & 00405.00 \\
\hline 103 & Def'a Risâle, alay1 & & 00030.00 \\
\hline 104 & En 'âm-1 Şerif ve Delâil-i Şerîf & & 00060.00 \\
\hline 105 & Mesnevî kıt'ası & & 00360.00 \\
\hline 106 & Mütenebbih alay1 & 00130.00 \\
\hline 107 & Def'a Kudûrî & & 136240.00 \\
\hline 108 & Risâle-i İbn-i İsa & & \\
\hline & Yekûn (akçe hesabıyla) & & \\
\hline & Yekûn (guruş hesabıyla) & & \\
\hline
\end{tabular}


Merhum-i mezbûrun bey' olunan [hüsn-i hat] ktt 'alarldır ki, ber-vech-i âtî zikr olunur: Bu kısımdaki eserler yazıldığı sıra üzere değil hattatlara göre tasnif edilmiştir.

\begin{tabular}{|l|l|c|c|}
\hline \multicolumn{1}{|l|}{ Hattatın adı ve eseri } & Aded & Fiyatı / Akçe \\
\hline & Şeyh Hamdullah: & \multicolumn{2}{l|}{} \\
\hline 001 & Karalama, bâ-hatt-1 evâhır-1 Şeyh & 01 & 00690.00 \\
\hline 002 & Kıt'a, bâ-hatt-1 evâhır-1 Şeyh & 01 & 01210.00 \\
\hline 003 & Salât-1 Şerife, bâ-hatt-1 evâhır-1 Şeyh & 01 & 01250.00 \\
\hline 004 & Def'a karalama bâ-hatt-1 Şeyh & 01 & 03260.00 \\
\hline 005 & Def'a karalama bâ-hatt-1 Şeyh & 01 & 02900.00 \\
\hline 006 & Karalama (?) bâ-hatt-1 Şeyh & 01 & 00520.00 \\
\hline 007 & Sülüs kıt'a, 2 satır, bâ-hatt-1 Şeyh & 01 & 02650.00 \\
\hline 008 & Muhrec, bâ-hatt-1 Şeyh & 01 & 00650.00 \\
\hline 009 & Def'a muhrec bâ-hatt-1 Şeyh & 01 & 00680.00 \\
\hline 010 & Kit'a, Tezkeranî... bâ-hatt-1 Şeyh & 01 & 03600.00 \\
\hline 011 & Sûre-i En'âm, bâ-hatt-1 Şeyh & 01 & 05000.00 \\
\hline 012 & En'âm-1 Şerîf, bâ-hatt-1 evâil-i Şeyh & 01 & 01520.00 \\
\hline 013 & Muhrec, bâ-hatt-1 evâil-i Şeyh & 01 & 00200.00 \\
\hline 014 & Çifte mıhrec, evâil-i Şeyh & 01 & 00900.00 \\
\hline 015 & Dua-nâme, bâ-hatt-1 evâil-i Şeyh & 00 & 00310.00 \\
\hline 016 & Def'a Sûre-i En'âm, bâ-hatt-1 Şeyh & 01 & 01610.00 \\
\hline 017 & Sûre-i En'âm ve gayri suver bâ-hatt-1 Şeyh & 01 & 02120.00 \\
\hline 018 & Nesih, 2 satır, bâ-hatt-1 Şeyh & 01 & 00309.00 \\
\hline 019 & Muhrec varak, Şeyh & 01 & 00070.00 \\
\hline 020 & Kıt'a, Kaale Rasulullah SAS, bâ-hatt-1 Şeyh & 01 & 01200.00 \\
\hline 021 & Kıt'a, Üzkürû... bâ-hatt-1 Şeyh & 01 & 01200.00 \\
\hline 022 & Besmeleli muhrec, bâ-hatt-1 Şeyh & 01 & 01000.00 \\
\hline 023 & Muhrec, Âyetü'l-Kürsî, bâ-hatt-1 Şeyh & 01 & 00600.00 \\
\hline 024 & Muhrec, Tezevvedû... bâ-hatt-1 Şeyh & 01 & 00600.00 \\
\hline 025 & Kıt'a, Men kanea'... bâ-hatt-1 Şeyh & 01 & 02400.00 \\
\hline 026 & Kıt'a Bismillah, bâ-hatt-1 Şeyh & 01 & 03630.00 \\
\hline 027 & Karalama, Ebü'd-Derdâ, bâ-hatt-1 Şeyh & 01 & 04610.00 \\
\hline 028 & Kıt'a, Lafza-i Celâl, bâ-hatt-1 Şeyh & 01 & 01000.00 \\
\hline 029 & Muhrec, Aleyke... bâ-hatt-1 Şeyh & 01 & 00260.00 \\
\hline
\end{tabular}




\begin{tabular}{|c|c|c|c|}
\hline 030 & Hurufât, 2 satır, bâ-hatt-1 Şeyh & 01 & 00840.00 \\
\hline 031 & Kıt'a, ed-Dünya... bâ-hatt-1 Şeyh & 01 & 00500.00 \\
\hline 032 & Kit'a, Ve anhü... bâ-hatt-1 Şeyh & 01 & 01200.00 \\
\hline 033 & Kit'a, Bismillah... bâ-hatt-1 Şeyh & 01 & 02800.00 \\
\hline 034 & Sülüs, 1 satır. bâ-hatt-1 Şeyh & 01 & 00420.00 \\
\hline 035 & Muhrec hızbü'l-bahr, bâ-hatt-1 Şeyh & 01 & 00120.00 \\
\hline 036 & Muhrec, Kaale Enes, bâ-hatt-1 Şeyh & 01 & 06000.00 \\
\hline 037 & Kıt'a, Kabl eli-İskender, bâ-hatt-1 Şeyh & 01 & 00210.00 \\
\hline 038 & Kit'a, el-Üstâdilân & 01 & 00420.00 \\
\hline 039 & Ketebe karalaması bâ-hatt-1 Şeyh & 01 & 07050.00 \\
\hline 040 & $\begin{array}{l}\text { Karalama, ke-Meselin, bâ-hatt-1 Şeyh } \\
\text { Efendi }\end{array}$ & 01 & 04000.00 \\
\hline 041 & Karalama, Len yebg1... bâ-hatt-1 Şeyh & 01 & 01500.00 \\
\hline 042 & Pûşideli karalama, bâ-hatt-1 Şeyh & 01 & 05000.00 \\
\hline 043 & Karalama, bâ-hatt-1 Şeyh & 01 & 07250.00 \\
\hline 044 & Karalama, İğtenim... bâ-hatt-1 Şeyh & 01 & 05900.00 \\
\hline 045 & Karalama, bâ-hatt-1 Şeyh & 01 & 01360.00 \\
\hline 046 & Murakka’ Besmeleli, bâ-hatt-1 Şeyh & 01 & 10500.00 \\
\hline 047 & Murakka' bâ-hatt-1 Şeyh & 01 & 10000.00 \\
\hline 048 & Murakka' bâ-hatt-1 Şeyh & 01 & 06050.00 \\
\hline 049 & Murakka' Bismillah, bâ-hatt-1 Şeyh & 01 & 14050.00 \\
\hline 050 & Murakka' kıt'a, bâ-hatt-1 Şeyh & 01 & 03021.00 \\
\hline 051 & Murakka' bâ-hatt-1 Şeyh & 09 & 04100.00 \\
\hline 052 & Def'a murakka' bâ-hatt-1 Şeyh & 01 & 32700.00 \\
\hline 053 & Muhrec, bâ-hatt-1 Şeyh & 01 & 00505.00 \\
\hline 054 & Mushaf-1 Şerîf, bâ-hatt-1 Şeyh & 01 & 19000.00 \\
\hline 055 & Def'a Mushaf-1 Şerîf, bâ-hatt-1 Şeyh & 01 & 60000.00 \\
\hline 056 & Sûre-i Münafikûn, bâ-hatt-1 Şeyh & 01 & 01000.00 \\
\hline 057 & Sûre-i Nebe' bâ-hatt-1 Şeyh & 01 & 01330.00 \\
\hline 058 & Def'a Sure-i Nebe' bâ-hatt-1 Şeyh & 01 & 01530.00 \\
\hline 059 & Nesih muhrec, bâ-hatt-1 Şeyh & 01 & 01010.00 \\
\hline 060 & Nesih ketebe, bâ-hatt-1 Şeyh & 01 & 00400.00 \\
\hline 061 & Def'a Şeyh, muhrec Şeyh & 00 & 02560.00 \\
\hline 062 & Muhrec, bâ-hatt-1 Şeyh & 01 & 01000.00 \\
\hline
\end{tabular}




\begin{tabular}{|c|c|c|c|}
\hline 063 & Çifte muhrec, evâhır-1 Şeyh & 01 & 00400.00 \\
\hline 064 & Kit'a, evâhir-i Şeyh & 01 & 00160.00 \\
\hline 065 & Muhrec, bâ-hatt-1 Şeyh & 01 & 00505.00 \\
\hline 066 & Muhrec, evâhır-1 Şeyh & 01 & 00300.00 \\
\hline 067 & Karalama, bâ-hatt-1 Şeyh & 01 & 01000.00 \\
\hline \multirow[t]{3}{*}{068} & Karalama, bâ-hatt-1 Şeyh & 01 & 00900.00 \\
\hline & Muhrec, bâ-hatt-1 şâkird-i Şeyh & 01 & 00204.00 \\
\hline & Hafiz Osman: & & \\
\hline 001 & Murakka' bâ-hatt-1 Hâfız Osman Efendi & 01 & 32100.00 \\
\hline 002 & Hilye-i Şerîfe bâ-hatt-1 Hâfız Osman & 01 & 01200.00 \\
\hline 003 & Çifte karalama, bâ-hatt-1 Hâfiz Osman & 02 & 02010.00 \\
\hline 004 & Kıt'a Tezkeranî, bâ-hatt-1 Hâfız Osman & 01 & 00410.00 \\
\hline 005 & $\begin{array}{l}\text { Def }^{\star} a \text { kit }{ }^{`} a \text {, Tezkeranî, bâ-hatt-ı Hâfız Os- } \\
\text { man }\end{array}$ & 01 & 01200.00 \\
\hline 006 & $\begin{array}{l}\text { Kit'a, Şerefü'l-Mü’min, bâ-hatt-1 Hâfiz Os- } \\
\text { man }\end{array}$ & 01 & 00410.00 \\
\hline 007 & $\begin{array}{l}\text { Kit'a Sadekatü's-(...), bâ-hatt-1 Hâfız Os- } \\
\text { man }\end{array}$ & 01 & 00910.00 \\
\hline 008 & Kit'a, bâ-hatt-1 Hâfız Osman Efendi & 01 & 01030.00 \\
\hline 009 & Beyt, bâ-hatt-1 Hâfız Osman & 01 & 00720.00 \\
\hline 010 & Kit'a, Men kāme, bâ-hatt-1 Hâfız Osman & 01 & 00852.00 \\
\hline 011 & Kıt'a, Bismillah, bâ-hatt-1 Hâfız Osman & 01 & 00900.00 \\
\hline 012 & $\begin{array}{l}\text { Kit'a, İnnellâhe cemîl, bâ-hatt-1 Hâfız Os- } \\
\text { man }\end{array}$ & 01 & 00612.00 \\
\hline 013 & $\begin{array}{l}\text { Kit'a, Allahu veliyyü’t-tevfik, bâ-hatt-1 Hâ- } \\
\text { fiz Osman }\end{array}$ & 01 & 01510.00 \\
\hline 014 & $\begin{array}{l}\text { Kit'a, Bismillahi teyemmünen, bâ-hatt-1 H. } \\
\text { Osman }\end{array}$ & 01 & 01130.00 \\
\hline 015 & Kıt'a, Ve külli ibnin, bâ-hatt-1 Hâfız Osman & 01 & 00800.00 \\
\hline 016 & Kit'a, Hallü'gays, bâ-hatt-1 Hâfız Osman & 01 & 01400.00 \\
\hline 017 & $\begin{array}{l}\text { Kit'a, Mine’t-tevâzu' bâ-hatt-1 Hâfız Os- } \\
\text { man }\end{array}$ & 01 & 00920.00 \\
\hline 018 & $\begin{array}{l}\text { Kit'a, Darbü'l-lisan... bâ-hatt-1 Hâfız Os- } \\
\text { man }\end{array}$ & 01 & 01200.00 \\
\hline 019 & $\begin{array}{l}\text { Kit'a, An Ömer ibni'l-Hattab, bâ-hatt-1 Hâ- } \\
\text { fiz Osman }\end{array}$ & 01 & 01100.00 \\
\hline
\end{tabular}




\begin{tabular}{|c|c|c|c|}
\hline 020 & Kıt'a, Ahbera..., bâ-hatt-1 Hâfiz Osman & 01 & 00740.00 \\
\hline 021 & $\begin{array}{l}\text { Kit'a, Selâmetü'l-insan... bâ-hatt-1 Hâfiz } \\
\text { Osman }\end{array}$ & 01 & 01260.00 \\
\hline 022 & Kıt'a, Kemal... bâ-hatt-1 Hâfız Osman & 01 & 00900.00 \\
\hline 023 & Kıt'a, Bi-melîk... bâ-hatt-1 Hâfız Osman & 01 & 01150.00 \\
\hline 024 & Kit'a, Bismillah, bâ-hatt-1 Hâfız Osman & 01 & 01020.00 \\
\hline 025 & Kıt'a, Ve anhü... bâ-hatt-1 Hâfız Osman & 01 & 01410.00 \\
\hline 026 & $\begin{array}{l}\text { Kit'a, Zikru'l-evliyâ... bâ-hatt-1 Hâfız Os- } \\
\text { man }\end{array}$ & 01 & 01130.00 \\
\hline 027 & Kıt'a, Yâ Galib... bâ-hatt-1 Hâfız Osman & 01 & 01240.00 \\
\hline 028 & Karalama, bâ-hatt-1 Hâfız Osman & 01 & 00910.00 \\
\hline 029 & Karalama, bâ-hatt-1 Hâfız Osman & 01 & 00450.00 \\
\hline 030 & Çifte karalama, bâ-hatt-1 Hâfız Osman & 01 & 00820.00 \\
\hline 031 & $\begin{array}{l}\text { Def'a çifte karalama, bâ-hatt-ı Hâfiz Os- } \\
\text { man }\end{array}$ & 01 & 01610.00 \\
\hline 032 & Def'a karalama, bâ-hatt-1 Hâfiz Osman & 01 & 01010.00 \\
\hline 033 & Def'a karalama, bâ-hatt-1 Hâfız Osman & 01 & 00640.00 \\
\hline 034 & Def'a karalama, bâ-hatt-1 Hâfız Osman & 01 & 01450.00 \\
\hline 035 & Def'a karalama, bâ-hatt-1 Hâfız Osman & 01 & 01010.00 \\
\hline 036 & $\begin{array}{l}\text { Kit'a, Yâ mecmea'l-mehâsin, bâ-hatt-1 Hâ- } \\
\text { fiz Osman }\end{array}$ & 01 & 00730.00 \\
\hline 037 & Besmeleli karalama, bâ-hatt-1 Hâfız Osman & 01 & 03150.00 \\
\hline 038 & Def'a karalama, bâ-hatt-1 Hâfız Osman & 01 & 00720.00 \\
\hline 039 & Kıt'a, Estağfirullah, bâ-hatt-1 Hâfız Osman & 01 & 01800.00 \\
\hline 040 & $\begin{array}{l}\text { Kit'a, Ve men beye'a... bâ-hatt-1 Hâfız Os- } \\
\text { man }\end{array}$ & 01 & 01650.00 \\
\hline 041 & Kıt'a, Besmeleli Hâfız Osman & 01 & 01100.00 \\
\hline 042 & Kıt'a, Kāle'n-Nebiyyü AS, Hâfız Osman & 01 & 00510.00 \\
\hline 043 & Kit'a, Allahümme... bâ hatt-1 Osman & 01 & 01509.00 \\
\hline 044 & Kıt'a El-birru'l-vefâ, Hâfız Osman & 01 & 01300.00 \\
\hline 045 & Kıt'a, Beyyin lehu... Hâfız Osman & 01 & 01100.00 \\
\hline 046 & Hurufât, sülüs ve nesih, Hâfız Osman & 01 & 01800.00 \\
\hline 047 & $\begin{array}{l}\text { Murakka' hurufât ve kasîde, bâ-hatt-1 Hâfız } \\
\text { Osman }\end{array}$ & 01 & 05000.00 \\
\hline 048 & Ta'limli, nesih hurufât, Hâfiz Osman & 01 & 01000.00 \\
\hline
\end{tabular}




\begin{tabular}{|c|l|c|c|}
\hline 049 & Ta'limli, nesih hurufât, Hâfız Osman & 01 & 03200.00 \\
\hline 050 & Ta'limli hurufât, Hâfı Osman & 01 & 05100.00 \\
\hline 051 & Ta'limli hurufât, Hâfı Osman & 01 & 07300.00 \\
\hline 052 & Ta'limli, hatt-1 Hâfız Osman & 01 & 00501.00 \\
\hline 053 & Hurufât, Hâfız Osman & 05 & 00600.00 \\
\hline 054 & Sülüs hurufât, Hâfız Osman & 14 & 00450.00 \\
\hline 055 & Def'a hurufât evrak 20 satır, Hâfız Osman & 00 & 00530.00 \\
\hline 056 & Hurufât evrak 19 satır, Hâfız Osman & 00 & 00550.00 \\
\hline 057 & Sülüs hurufât 15 satır, Hâfız Osman & 00 & 00800.00 \\
\hline 058 & Def'a hurufât, Hâfız Osman & 01 & 00405.00 \\
\hline 059 & Hilye-i Şerîf, bâ-hatt-1 Hâfız Osman & 01 & 02410.00 \\
\hline 060 & Def'a, Hilye-i Şerîf, bâ-hatt-1 Hâfız Osman & 01 & 02510.00 \\
\hline 061 & Ruganlı Hilye-i Şerîf, Hâfız Osman & 01 & 01330.00 \\
\hline 062 & Kit'a, Tezkeranî... bâ-hatt-1 Osman & 01 & 01500.00 \\
\hline 063 & Duanâme, bâ-hatt-1 Hâfız Osman & 01 & 24000.00 \\
\hline 064 & Ed'ıyye, bâ-hatt-1 Hâfız Osman & 01 & 01900.00 \\
\hline 065 & Murakka' hurufât, Hâfız Osman & 01 & 08000.00 \\
\hline 066 & Hurufât, bâ-hatt-1 Hâfız Osman & 01 & 02350.00 \\
\hline 067 & Hurufât, bâ-hatt-1 Hâfız Osman & 01 & 04050.00 \\
\hline 068 & Hurufât, bâ-hatt-1 Hâfız Osman & 01 & 03600.00 \\
\hline 069 & Hurufât, bâ-hatt-1 evâil-i Hâfız Osman & 01 & 03000.00 \\
\hline 070 & Murakka' Besmeleli, Hâfız Osman & 01 & 02300.00 \\
\hline 071 & Muhrec, bâ-hatt-1 Hâfız Osman & 01 & 01330.00 \\
\hline 072 & Simli murakka' bâ-hatt-1 Hâfız Osman & 01 & 02400.00 \\
\hline 073 & Sûre-i Nebe-i Şerîf, bâ-hatt-1 Hâfız Osman & 01 & 18000.00 \\
\hline 074 & Mücelled, muhrec, bâ-hatt-1 Hâfız Osman & 00 & 03000.00 \\
\hline 075 & Karalama, bâ-hatt-1 Hâfı Osman & 00 & 01320.00 \\
\hline 076 & Muhrec, Hâfız Osman & 01 & 00305.00 \\
\hline 077 & Muhrec, Hâfız Osman & 00 & 00620.00 \\
\hline 078 & Çifte muhrec, Hâfız Osman & 00 & 01100.00 \\
\hline 079 & Muhrec, Hâfız Osman & 01 & 00710.00 \\
\hline 080 & Kıt'a, bâ-hatt-1 Hâfız Osman & 01 & 00600.00 \\
\hline 081 & Kıt'a, bâ-hatt-1 Hâfız Osman & 00740.00 \\
\hline 082 & Karalama, bâ-hatt-1 Hâfız Osman & 00610.00 \\
\hline
\end{tabular}




\begin{tabular}{|c|c|c|c|}
\hline 083 & Def'a kıt'a, bâ-hatt-1 Hâfız Osman & 01 & 01210.00 \\
\hline 084 & Karalama, bâ-hatt-1 Hâfız Osman & 01 & 00435.00 \\
\hline \multirow[t]{4}{*}{085} & Def'a karalama, bâ-hatt-1 Hâfız Osman & 01 & 00910.00 \\
\hline & Muhrec, bâ-hatt-1 Osman & 01 & 01640.00 \\
\hline & $\begin{array}{l}\text { Murakka' sülüs, bâ-hatt-1 Cezerî Osman } \\
\text { Efendi }\end{array}$ & 01 & 020230.00 \\
\hline & Mustafa Dede b. Şeyh Hamdullah & & \\
\hline 001 & Mushaf-1 Şerîf bâ-hatt-1 Dede & 01 & 97000.00 \\
\hline 002 & Nesih, 2 satır, bâ-hatt-1 Dede & 01 & 01010.00 \\
\hline 003 & Kit'a, Şakir bâ-hatt-1 Dede & 01 & 02040.00 \\
\hline 004 & Kit'a, Kāle’n-Nebiyyü AS, bâ-hatt-1 Dede & 01 & 00400.00 \\
\hline 005 & Muhrec, Kāle..., bâ-hatt-1 Dede & 01 & 00600.00 \\
\hline 006 & Muhrec, Kāle..., 2 satır, bâ-hatt-1 Dede & 01 & 00245.00 \\
\hline 007 & Murakka' bâ-hatt-1 Mustafa Dede & 01 & 05000.00 \\
\hline 008 & Nesih, evâil-i Dede & 01 & 00260.00 \\
\hline 009 & Kit'a, bâ-hatt-1 Dede & 00 & 00210.00 \\
\hline 010 & Kit'a, Dede & 01 & $00100 ? .00$ \\
\hline 011 & Def'a kıt'a Dede & 01 & 00330.00 \\
\hline \multirow[t]{2}{*}{012} & Kit'a, bâ-hatt-1 Dede & 01 & 00610.00 \\
\hline & Hasan Çelebi & & \\
\hline 001 & Mushaf-1 Şerîf, hatt-1 Hasan Çelebi & 01 & 19200.00 \\
\hline 002 & Hatt-1 Hasan Çelebi, parça varak & 05 & 00210.00 \\
\hline 003 & Kit'a bâ-hatt-1 Hasan Çelebi & 01 & 00215.00 \\
\hline 004 & Bismillah 1 satır, bâ-hatt-1 Hasan Çelebi & 01 & 00111.00 \\
\hline 005 & Hurufât-1 Hasan Çelebi & 01 & 00380.00 \\
\hline \multirow[t]{3}{*}{006} & Muhrec, Hasan Çelebi & 01 & 00230.00 \\
\hline & Misbah'dan varak Karahisarî & 01 & 00210.00 \\
\hline & Seyyid Abdullah, Yedikuleli & & \\
\hline 001 & $\begin{array}{l}\text { Kit'a, Min mezhebî... bâ-hatt-1 Seyyid Ab- } \\
\text { dullah }\end{array}$ & 01 & 00530.00 \\
\hline 002 & $\begin{array}{l}\text { Kit'a, Besmele... bâ-hatt-1 Seyyid Abdul- } \\
\text { lah }\end{array}$ & 01 & 00660.00 \\
\hline 003 & Muhrec, bâ-hatt-1 Seyyid Abdullah & 01 & 01430.00 \\
\hline 004 & Nesih, muhrec, bâ-hatt-1 Seyyid Abdullah & 01 & 00350.00 \\
\hline 005 & Hilye-i Şerîf, Seyyid Abdullah Efendi & 01 & 00415.00 \\
\hline
\end{tabular}




\begin{tabular}{|c|c|c|c|}
\hline 006 & Sûre-i En'âm, bâ-hatt-1 Seyyid Abdullah & 01 & 04650.00 \\
\hline 007 & En'âm-1 Şerîf, bâ-hatt-1 Seyyid Abdullah & 01 & 04500.00 \\
\hline 008 & Kıt'a karalama, bâ-hatt-1 Seyyid Abdullah & 00 & 00210.00 \\
\hline \multirow[t]{2}{*}{009} & Muhrec, bâ-hatt-1 Seyyid Abdullah & 00 & 00710.00 \\
\hline & Hüseyin Hablî / İpçi Hüseyin & & \\
\hline 001 & Kit'a bâ-hatt-1 İpçi Hüseyin Efendi & 01 & 00153.00 \\
\hline 002 & Karalama bâ-hattı İpçi & 01 & 00309.00 \\
\hline 003 & Hilye-i Şerîf, bâ-hatt-1 İpçi Hüseyin Efendi & 01 & 00480.00 \\
\hline 004 & Kıt'a, Kāle Rasulüllah AS, bâ-hatt-1 İpçi & 01 & 00720.00 \\
\hline 005 & Murakka' bâ-hatt-1 İpçi Hüseyin Efendi & 01 & 00480.00 \\
\hline 006 & Murakka' bâ-hatt-1 İpçi Hüseyin Efendi & 01 & 00600.00 \\
\hline 007 & Def'a murakka' bâ-hatt-1 İpçi Hüseyin & 01 & 00600.00 \\
\hline 008 & $\begin{array}{l}\text { Def'a Sûre-i En'âm, bâ-hatt-1 Hüseyin } \\
\text { Efendi }\end{array}$ & 01 & 00800.00 \\
\hline \multirow[t]{19}{*}{009} & Def'a hat Hüseyin Efendi & & 00240.00 \\
\hline & Muhtelif hattatlar & & \\
\hline & $\begin{array}{l}\text { Murakka' hurufât, bâ-hatt-1 Eğrikapı1ı [M. } \\
\text { Rasim Ef] }\end{array}$ & 01 & 00620.00 \\
\hline & Meşk, bâ-hatt-1 Eğrikapılı & 01 & 00125.00 \\
\hline & Mushaf-1 Şerîf, bâ-hatt-1 İbrahim Efendi & 01 & 24000.00 \\
\hline & Mushaf-1 Şerîf, bâ-hatt-1 Nefes-zâde & 01 & 26000.00 \\
\hline & Mushaf-1 Şerîf, bâ-hatt-1 Nefes-zâde & 01 & 03000.00 \\
\hline & Karalama, bâ-hatt-1 Hoca-zâde & 00 & 00000.00 \\
\hline & Cüz' bâ-hatt-1 Hâfiz Ali [Afif damadı?] & 01 & 00310.00 \\
\hline & Karalama bâ-hatt-1 Mehmed Bey & 01 & 00300.00 \\
\hline & Evrâd-1 Hafta, bâ-hatt-1 Emir Efendi & 01 & 02400.00 \\
\hline & Nesih muhrec, bâ- hatt-1 (...) varak & & \\
\hline & $\begin{array}{l}\text { Besmeleli murakka' bâ-hatt-1 Ağakapılı [İs- } \\
\text { mail Ef] }\end{array}$ & 01 & 00520.00 \\
\hline & Karalama, bâ-hatt-1 Ağakapılı & 01 & 00050.00 \\
\hline & Hatt-1 Ağakap1l1, varak & 14 & 00180.00 \\
\hline & Hatt-1 Râsim, alayı & 04 & 00065.00 \\
\hline & Karalama, bâ-hatt-1 İsmail Efendi & 01 & 00065.00 \\
\hline & Sûre-i En'âm, bâ-hatt-1 İsmail Efendi & 01 & 01650.00 \\
\hline & Hat, Emir Efendi 2 varak & 02 & 00060.00 \\
\hline
\end{tabular}




\begin{tabular}{|c|c|c|}
\hline Muhrec, Emir Efendi & 01 & 00210.00 \\
\hline Karalama, bâ-hatt-1 Emir Efendi & 01 & 00300.00 \\
\hline Hurufât, bâ-hatt-1 Derviş Ali & & \\
\hline Muhrec, Derviş Ali & 00 & 12000.00 \\
\hline Ta'limli hurufât, bâ-hatt-1 Derviş Ali-i Sanî & 00 & 00300.00 \\
\hline Muhrec, bâ-hatt-1 Anber Ağa & 01 & 00220.00 \\
\hline Kit'a, bâ-hatt-1 Tophaneli & 01 & 00220.00 \\
\hline Muhrec, bâ-hatt-1 Tophaneli & 01 & 00140.00 \\
\hline Nesih muhrec, bâ-hatt-1 Dede Mehmed & 01 & 00150.00 \\
\hline Murakka', bâ-hatt-1 Yahya Efendi & 01 & 00321.00 \\
\hline Çifte karalama & 01 & 00300.00 \\
\hline Afif İbrahim Efendi’nin Hat Malzemesi & & \\
\hline Hatt-1 (...) varak & 19 & 00305.00 \\
\hline Def a hatt-1 (...) varak & 02 & 00039.00 \\
\hline Hurufât-1 hat & 00 & 00600.00 \\
\hline Hat varak & 18 & 01380.00 \\
\hline Def'a hat varak & 13 & 00159.00 \\
\hline Kesilmiş âbâdî deste & 05 & 03700.00 \\
\hline Def'a kesilmiş âbâdî deste & 05 & 03700.00 \\
\hline Def'a kesilmiş âbâdî deste & 05 & 03700.00 \\
\hline Def'a kesilmiş âbâdî deste & 05 & 03700.00 \\
\hline Def'a kesilmiş âbâdî deste & 05 & 03700.00 \\
\hline Def'a kesilmiş âbâdî deste & 01 & 00740.00 \\
\hline Telhis kâğ $1 d_{1}$, deste & 08 & 01090.00 \\
\hline Cild & 00 & 00030.00 \\
\hline Evrâk-1 perîşan & 00 & 00155.00 \\
\hline Def'a, evrak-1 perîşan & 00 & 00250.00 \\
\hline Def'a evrak & 00 & 00505.00 \\
\hline Eczâ-y1 âbâdî & 00 & 00950.00 \\
\hline Def'a cild & 01 & 00300.00 \\
\hline Cild, maa evrak & 00 & 00400.00 \\
\hline Âbâdî kâğıt parçası & 00 & 01000.00 \\
\hline Def'a evrak & 00 & 00100.00 \\
\hline Def'a evrak & 00 & 00105.00 \\
\hline
\end{tabular}




\begin{tabular}{|c|c|c|}
\hline Def'a parça âbâdî & 00 & 00315.00 \\
\hline Def'a âbâdî evrak & 00 & 00305.00 \\
\hline Evrak, alay1 & 00 & 00900.00 \\
\hline Evrâk-1 Leylâ vü Mecnûn & 00 & 00105.00 \\
\hline F1stık kâğgd1 & 00 & 00125.00 \\
\hline Def'a parça âbâdî & 00 & 00805.00 \\
\hline Def'a parça âbâdî & 00 & 00520.00 \\
\hline Âbâdî evrak-1 perîşan & 00 & 00705.00 \\
\hline Def'a âbâdî parçası & 00 & 00504.00 \\
\hline Def'a evrak & 00 & 00210.00 \\
\hline Keşmîrî âbâdî deste & 01 & 00163.00 \\
\hline Def'a âbâdî evrak & 17 & 01205.00 \\
\hline Elvan âbâdî evrak & 19 & 00605.00 \\
\hline Penbe âbâdî evrak & 00 & 01040.00 \\
\hline Bir miktar ebrî kâğıd & 00 & 00430.00 \\
\hline Kebîr âbâdî kâğıt & 08 & 01270.00 \\
\hline Def'a âbâdî evrak & 07 & 00805.00 \\
\hline Def'a kebîr âbâdî deste & 01 & 03550.00 \\
\hline Def'a âbâdî varak & 03 & 00320.00 \\
\hline Âbâdî kâğıt deste & 01 & 00903.00 \\
\hline Battal İstanbul kâğıdı & 01 & 01700.00 \\
\hline Semerkand âbâdî deste & 01 & 00640.00 \\
\hline Def'a âbâdî deste & 01 & 00640.00 \\
\hline Def'a âbâdî deste & 01 & 00640.00 \\
\hline Def'a âbâdî deste & 01 & 00640.00 \\
\hline Def'a âbâdî deste & 02 & 01280.00 \\
\hline Def'a âbâdî deste & 02 & 01280.00 \\
\hline Def'a âbâdî deste & 02 & 01280.00 \\
\hline Def'a âbâdî deste & 01 & 00640.00 \\
\hline Def'a âbâdî deste & 04 & 02560.00 \\
\hline Def'a âbâdî deste & 02 & 01280.00 \\
\hline Def'a âbâdî deste & 06 & 03840.00 \\
\hline Def'a âbâdî deste & 02 & 01280.00 \\
\hline Def'a âbâdî deste & 02 & 01280.00 \\
\hline
\end{tabular}




\begin{tabular}{|c|c|c|}
\hline Def'a âbâdî deste & 09 & 05760.00 \\
\hline Kesilmiş Hatâî âbâdî deste & 07 & 03000.00 \\
\hline Hat tahta $[\mathrm{s} 1]$ & 04 & 00309.00 \\
\hline Bir miktar âbâdî kâğıt & 00 & 00750.00 \\
\hline Def'a âbâdî deste & 01 & 00370.00 \\
\hline Def'a âbâdî varak & 15 & 00310.00 \\
\hline Def'a âbâdî varak & 17 & 00260.00 \\
\hline Âbâdî kâğıt deste & 02 & 00460.00 \\
\hline Âbâdî kâğıt deste & 02 & 00600.00 \\
\hline Def'a âbâdî deste & 02 & 00560.00 \\
\hline Def'a âbâdî deste & 02 & 00500.00 \\
\hline Def'a âbâdî deste & 02 & 00534.00 \\
\hline Def'a âbâdî deste & 01 & 00210.00 \\
\hline Âbâdî kâğıt varak & 21 & 00300.00 \\
\hline Def'a telhîs deste & 02 & 00300.00 \\
\hline Def'a âbâdî kâğıt varak & 05 & 00300.00 \\
\hline Bir miktar âbâdî & 00 & 00150.00 \\
\hline Def'a telhîs kâğıdı deste & 05 & 00711.00 \\
\hline F1st1k kâğ1d1 deste & 01 & 00075.00 \\
\hline Def'a fistık kâğıdı deste & 10 & 00240.00 \\
\hline İyi damga kâğıdı deste & 01 & 00120.00 \\
\hline Def'a fistık kâğıdı deste & 05 & 00220.00 \\
\hline Def'a fistık kâğıdı deste & 05 & 00160.00 \\
\hline Def'a fistık kâğıdı deste & 05 & 00135.00 \\
\hline Def'a fistık kâğıdı deste & 10 & 00300.00 \\
\hline Arslan damga kâğıdi & 13 & 00500.00 \\
\hline Def'a iyi damga kâğıdı deste & 03 & 00030.00 \\
\hline İstanbul ve fistık kâğıdı & 07 & 00531.00 \\
\hline Def'a fistık kâğıdı & 05 & 00150.00 \\
\hline Telhîs ve fistık kâğıdı & 07 & 00370.00 \\
\hline Kalemtıraş & 03 & 00360.00 \\
\hline Def'a kalemtıraş & 05 & 00300.00 \\
\hline Def'a kalemtıraş & 20 & 00600.00 \\
\hline Müşemma' ve mum & 00 & 00015.00 \\
\hline
\end{tabular}




\begin{tabular}{|l|l|c|c|}
\hline & Bir miktar kalem & 00 & 03000.00 \\
\hline & Yekûn (akçe hesabiyla) & & 799530. \\
\hline & Yekûn (guruş hesabıyla) & & 6662.5 \\
\hline
\end{tabular}

Hattat Afif İbrahim Efendi'nin 18.05.1768 tarihinde yazılan muhallefâtının hat sanatına ve kütüphanesine müteallik kısmı bundan ibarettir. Bu makale Afifi İbrahim Efendi'nin bilhassa hat tarihindeki müstesna yerini tespit maksadiyla yazıldığı için onun oldukça zengin diğer her türden eşyası buraya dâhil edilmedi. Ancak her şeyin tek tek yazılıp satılarak nakde çevrilmesi ile de iş bitmemiştir. Verese arasında çıkan anlaşmazlık sonucu miras taksimi nakden yapılamamış, ancak üç sene sonra 01.03 .1771 'de yapılabilmiştir. Anlaşmazlık sebebi ise yine bu değerli hat koleksiyonundan kaynaklanmış. 1768'deki tespitte muhallefata yazılmayan ve 875 kuruş hediye bedeli takdir edilen üç aded Mushaf-1 Şerifi merhum Afif Efendi'nin eşi Ayşe Hanımla küçük kızı Rukıyye Hanım'ın vekilleri hattat olduğu anlaşılan damat Hafız Ali Efendi alı koymuş. Hâfız Ali Efendi'nin niyeti bu Mushafların ailede kalması imiş. 1771'de tekrar kaleme alınan birkaç maddelik borç-alacak listesinde daha önce görülmeyen bir Mushaf-1 Şerif daha var ki, buna da o gün 578 kuruş hediye bedeli ile elden çıkarılmış. Ama Afif İbrahim Efendi'nin borçları mevcut mirasla kapatılmadığından, daha sonra o Mushafların da mecburen bu listeye konması kararlaştırılmış. Ortaya çıkan son tablo belgede şu şekilde özetlenmiştir:

"Müteveffâ-yı mezbûrun bâlâda mezkûr bilcümle terekesi üç bin dört yüz yirmi beş guruş olup ve bilcümle düyûnu üç [bin] dört yüz yirmi beş guruşa bâliğ olmă̆la veresesine taksim için bir akçe baakî kalmayıp mezkûr Ali Efendi'nin bâlâda mezkûr düyûn ve mesârifâtı içün veresenin mukaddemâicâzet ve nizấları olmuşdu. El-hâletü hâzihi verese-i mezbûrât husus-i mezkûre müteallika davadan Ali Efendi'nin zimmetini ibrâ edip kal'-ı nizâ' eyledikleri bu mahalle şerh olundu."

09.11.1770 (20.B.1184)'de Afif İbrahim Efendi'nin en büyük kızı ve “Afif damadı" diye meşhur Hattat Osman Efendi'nin eşi Emetullah Hanım vefat etmiştir. Mahkemece muhallefatı kayda geçirilen Emetullah Hanım'ın vârisleri olarak; kocası es-Seyyid Osman Ağa b. el-Hac Osman ile vâlidesi Ayşe Hanım, kız kardeşleri Fatma ve Rukıyye'nin adları geçmektedir. 3689 guruş tutan Emetullah Hanım'ın bu mirasından 1400 guruşunu Osman Efendi almış, arta kalanını ise annesi ve iki kız kardeşi arasında taksim edilmiştir. ${ }^{5}$

$\mathrm{Bu}$ arada Karaca Ahmed mezarlığının İsfalt tesislerine yakın olan bölümünde 6079 numara ile envantere girdiği anlaşılan bir mezar taşına göre bir başka Hat-

4 Şer'î Siciller Arşivi, Kısmet-i Askeriye mahkemesi 346 / 49 b.

5 Kismet-i Askeriye... $346 / 42,43$. 
tat İbrahim Afif (1798-1816) daha vardır. Çok genç yaşta vefat eden ve Hâfız da olduğu taşında yazılı bulunan bu İbrahim Afif Efendi'nin büyük Afif İbrahim Efendi'yle arasında bir yakınlık görülmüyor. Afif İbrahim Efendi'nin vefatında yaşı küçük olduğu bilinen kızı Rukıyye Hanım'dan dolayı bir yakınlık düşünülebilirse de bu konuda fazla söze hâcet yoktur. Bu mezar taşında şu yazı vardır:

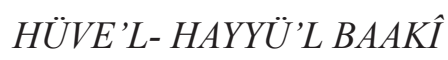

Bir acâib derde düştüm bulmadım asla devâ / Derdim efzûn oldu umdukça tabiblerden devâ

Genç yaşımda ansızın bâd-ı ecel erdi bana / Ey benim dertli babam ağlayıp figan etme bana

Hâla ser tavukçuyân-ı Hazret-i Şehriyarî / el-Hac Abdullah Ağa-zâde on dokuz yaşıında

Vefat eden es-Seyyid Hâfiz Hattat / İbrahim Afif Efendi'nin ruhîyçün El-Fatiha 29.N. 1231

Harrarahû Ömerü'l-Vasfí. 


\section{Kaynakça}

Dere, Ömer Faruk, Hattat Hafiz Osman Efendi, İstanbul, Korpus Kültür Sanat Yayıncilik, 2005.

Müstakim-zâde, Tuhfe-i Hattatîn, İbnülemin Mahmud Kemal neşri, İstanbul, Türk Tarih Encümeni Külliyatı, 1928.

Serin, Muhittin, Hattat Şeyh Hamdullah, 2. bs., İstanbul, Kubbealtı Neşriyat, 2007.

Şer’̂̂ Siciller arşivi, Kısmet-i Askeriye mahkemesi 346 / 49 b.

Şer’î Siciller arşivi, Kismet-i Askeriye... 346 / 42, 43. 
